\title{
"End of the Reel"
}

\section{Calendar of Events and Affiliate Information}

FLEAT III/IALL'97
We welcome the submission of information on upcoming events from our readers. Send items to the Editor-in-Chief

\author{
Pete Smith \\ IALL Journal \\ Language Acquisition Center \\ University of Texas at Arlington \\ P.O. Box 19557 \\ Arlington, TX 76019 \\ email: pete@langlab.uta.edu \\ fax: (817) 794-5147
}

The 1997 biennial meeting of the International Association for Learning Laboratories (IALL) will be held jointly with the third Foreign Language Education and Technology Conference (FLEAT III) at the University of Victoria in British Columbia, August $12-16,1997$. The conference is sponsored jointly by IALL and the Language Lab Association of Japan (LLA) and is the first time the conference is being held outside of Japan.

For more information, contact FLEATIII@CALL.UVIC.CA or check out the World Wide Web page at: http:// ikra.call.uvic.ca/LangCen/FLEAT/fleat1.html.

\section{IALL Affiliate Events}

\section{SWCOLT}

Northeast Conference on Foreign Languages
April 11-13, 1996. Southwest Conference on Language Teaching. Albuquerque, NM. Contact: Joann K. Pompa, Mountain Pointe High School, 4201 E. Knox Rd., Phoenix, AZ 85044.

April 18-21, 1996 in New York. Contact: Rebecca Kline, Penn State University, 316 Burrowes Bldg., University Park, PA 16802-6203. 
CALICO 1996 Annual Symposium, hosted by the University of New Mexico. Theme: "Distance Learning." Preconference Workshops: May 27-28; Courseware Fair: June 1; Regular Sessions: Wednesday, May 29-31. Information: http://agoralang.com/calico/calconf.html.

Pacific Northwest Council on Foreign Languages

LLA July 29-31, 1996, at Takushoku University, 25 miles west of Tokyo. Contact conference organizer Akio Iwasaki at iwasakia@chiba.dendai.ac.jp. The theme of the meeting is "The Changing Learning Environment and Foreign Language Education."

ACTFL The 30th Annual Meeting of ACTFL will be held November 22-24, 1996, at the Marriott Hotel in Philadelphia, PA. The theme of the meeting is "One Profession-Working Together." Information: http://www.infi.net/ actfl/ meeting.html.

\section{Announcements}

New Journal

The University of Alberta announces the Journal for Intercultural Second/Foreign Language Teaching: Didactics and Methodology for German as a Foreign Language, an electronic schlolarly publication. The first issue is expected May 1, 1996. Further information can be obtained at the following address: http://www.ualberta.ca/ german/ejournal/ejournal.html.

NNELL The National Network for Early Language Learning (NNELL) is a national organization dedicated to the advocacy of foreign language instruction for all students, kindergarten through 8th grade. The new official publication of NNEL is Learning Languages: The Journal of the National Network for Early Language Learning. Information about this organization and its journal can be obtained by contacting Nancy Rhodes, Executive Secretary, Center for Applied Linguistics, 1118 22nd St. NW, Washington, DC, 20037.

Culpeper Conference

October $18-19,1996$, the Tucker Multimedia Center for Foreign Languages at Washington and Lee University in Lexington, Virginia, will host a conference-"Ingenious Methodologies through Technology"-sponsored by the Charles E. Culpeper Foundation. 
Over the last decade, the Culpeper Foundation has awarded numerous colleges and universities with funds for developing programs in foreign languages and technologies. All grant recipients have been extended a special invitation to participate in the conference, as well as other schools in the MidAtlantic region.

For further information, contact Dick Kuettner, Conference Coordinator, at Washington and Lee University. The number of participants is limited to one hundred.

\section{Product News}

Agora Language Marketplace

\section{World of Reading}

\section{Position Vacancies} The Westminster Schools Instructional Technology Coordinator for Foreign Languages
The IALL Journal makes this space available for our commercial members to announce new products and services. Members are encouraged to submit product announcements to the Editorin-Chief.

The Agora Showcase is a juried showcase of the newest, quality materials by language professionals. The Showcase and Agora Publishing Group offer authors of low-volume materials a method of peer review and distribution of products that may be too specialized for large-scale publishers. This service is offered in cooperation with Schoenhof's Foreign Books. Submissions will be accepted quarterly. More information regarding these services can be obtained on the WWW: http://agoralang.com/showcaseform.html. The first Showcase is scheduled for release April 1. Point your Web browser to http:// agoralang.com.com/showcase.html!

World of Reading's online catalogue at is now available at http://www.wor.com. World of Reading offers foreign language software in over 30 languages and ESL software for children and adults all at prices below retail prices. A variety of foreign language books, tapes and videos is also available.

The Westminster Schools, Atlanta, GA, announces the following position: Instructional Technology Coordinator for Foreign Languages.

This is a faculty position, responsible for all aspects of the operation of the language laboratory, including audio, video, and computer resources. Duties include scheduling and coordinating all classes in the lab, preparing materials prior to students' arrival in lab, assisting teachers with lab classes and with use of lab equipment, maintaining equipment and keep- 
ing files and inventory of materials. Keeps current on trends in technology and language teaching, and helps teachers with technology projects. Has proficiency in using computers for instruction, and teaches one language class.

Master's degree (M. A.) or equivalent desirable in language field ; training as language teaching professional highly desirable (or four to ten years related experience and/or training; or equivalent combination of education and experience.)

Demonstrated foreign language expertise (teaching experience, knowledge of foreign language methodology, instructional design) along with experience and expertise with instructional media, including digital audio, CD, camcorders, satellite technology, interactive video, and multimedia.

Interested candidates should contact:

Dr. Anna Boller

Language Dept. Chair

The Westminster Schools

1424 W. Paces Ferry Rd. NW

Atlanta, GA 30327

404-609-6109

email: boller@mindspring.com

Corrections The following IALL members were omitted from the membership listing published in the last issue:

John S. Huy

Ermal Garinger Academic Resource Center

University of Kansas

4069 Wescoe Hall

Lawrence KS 66045

913-864-4759

huy@kuhub.cc.ukans.edu

Robin McClanahan

Anderson Language Technology Center

Hellems 156, Campus Box 239

University of Colorado-Boulder

Boulder CO 80309-0239

303-492-6217

mcclanah@spot.colorado.edu 


\section{IALL Publications}

Enter charges for desired publications. Complete and attach next page.

IALL. Monographs:

\begin{tabular}{lll}
\multicolumn{2}{c}{ Price } & Quant. Total \$ \\
Memb. & Non.
\end{tabular}

Task-Based Activities

$\$ 10 \quad \$ 15$

Task-Based II

$\$ 10$

$\$ 15$

Designing the Learning Center of the Future

$\$ 10$

$\$ 15$

$\$ 15$

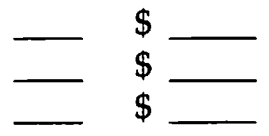

IALL Lab Design Kit (First Edition)

$\$ 15$

$\$ 25$

$\$$

Video Tours

IALL'89 - ‘95

$\$ 15$

$\$ 25$

$\$$

\section{Conference Presentations on Video}

Contact Tom Browne for complete listing. See address next page.

FLEAT II

$\$ 15$

$\$ 25$

$\$$

\section{Journals}

NALLD Journal Back Issues Vol. 1 - 19

$\$ 1$

$\$ 2$

$\underline{-}$

$\$$

List issues:

JETT Back Issues Vol. 20 - 22

$\$ 5$

$\$ 10$

$\$$

List issues:

IALL Journal Back Issues Vol. 23 - 28

$\$ 7.50$

$\$ 12.50$

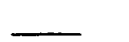

$\$$

List issues:

Total publications charges

$\$$

Remit check payable in U.S. funds to IALL. Payment must accompany all orders. 


\section{IALL Membership and Publications Order Form/Invoice}

Name

Position

Department

Institution

Address

City

State

Zip

Country

Phone

FAX

Email address

Check other professional organizations to which you belong:

AECT

ACTFL

CALICO TESOL

Check if you need IALL Regional Group Membership Information:

Check desired membership category and charges:

$\begin{array}{ll}\text { Educational Member (Voting) } & \$ 40.00 \\ \text { Commercial Member (Non-Voting) } & \$ 55.00 \\ \text { Library Subscription (Non-Voting) } & \$ 40.00 \\ \text { Student member* (Voting) } & \$ 15.00\end{array}$

*Signature of sponsoring IALL member required for student membership.

Subtotal Membership Charges:

Add Postage (if outside North America): $\quad \$ 15.00$

Publications charges (attach previous page):

$\$$

$\$$

$\$$

Total all charges (membership + postage + desired publications) $\$$

Remit check payable in U.S. funds to IALL. Payment must accompany all orders.

Mail invoice and check to: Tom Browne, IALL Business Manager

Humanities Resource Center

Macalester College

Saint Paul, MN 55105-1899

Phone: (612) 696-6336

Fax: (612) 696-6435

Email: Browne@macalstr.edu 


\title{
Advertising Guidelines/Rates April 1996
}

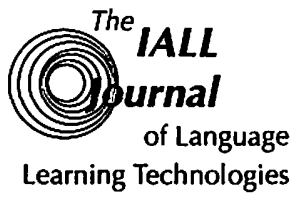

...provides exposure for your product or service to teachers, faculty, learning laboratory directors, and media specialists working to improve language learning through technology. Topics include feature-length articles dealing with the effective uses of technology (audio labs, computers, television, satellite receivers, and interactive video) and with ideas and insights about lab management, design and use.

\section{Acceptable Material:}

Non-bled; high-quality photomechanical transfer prints on film or paper (PMT, Copyproof); offset file negatives (high-density litho film right reading with emulsion side down, line and halftone combination as complete montages only). Halftones: 85-120 lines

\section{Rates:}

Journal Size 7" $\times 10^{\prime \prime}$

Full page (ad copy: 6" $\left.\times 9^{\prime \prime}\right)$

Half page (ad copy: $\left.2^{1 / 2} 2^{\prime \prime} \times 9^{\prime \prime}, 6^{\prime \prime} \times 4^{\prime \prime}\right)$

Covers $2 \& 3$

1 Insertion

$\$ 275$

$\$ 200$

$\$ 350$

$\$ 400$

\section{Insertions}

$\$ 250$

$\$ 175$

$\$ 325$

$\$ 375$

We send tearsheets with invoice.

\section{Schedule:}

Issues
Winter
Spring
Fall

Closing Deadline

December 1

April 1

August 1
Publication

February

June

October

\section{Send Insertion Orders, All Copy and Layout To:}

\author{
Harold H. Hendricks, IALL Advertising Manager \\ Humanities Research Center \\ Brigham Young University \\ 3060 JKHB \\ P.O.Box 26098 \\ Provo, UT 84602-6098 \\ Phone: (801) 378-6448
}

We send written confirmation for all ad reservations received. 


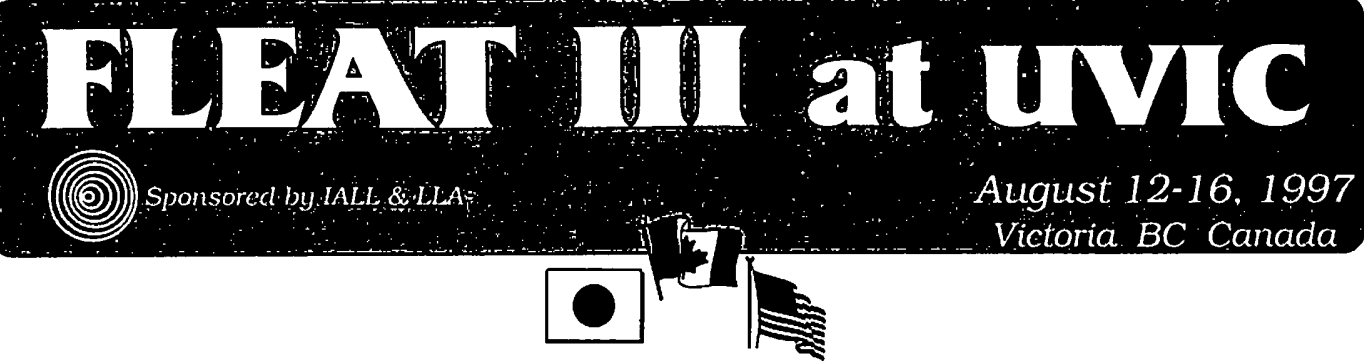

The third in a series of jointly sponsored conferences and the first to be held in North America. Sponsors: LLA, Language Laboratory Association of Japan and IALL, the International Association for Learning Laboratories.

\title{
August 12 - 16, 1997 Victoria BC Canada
}

Victoria is Canada's westernmost city, situated on the southern tip of Vancouver Island, in one of Canada's mildest climates. Famous for its gardens, sailing, fishing and close to spectacular National and Provincial parks, Victoria is a year-round destination for international tourists. Plan to arrive in Victoria by air via Vancouver or Seattle, or land there and cruise in by ferry through the islands and sounds. The University of Victoria is renowned for its state-of-the-art CALL Facility and looks forward to hosting this important conference.

\section{VICTORIA and VANCOUVER ISLAND}

$\begin{array}{ll}\text { * The Butchart Gardens } & \text { Whale Watching } \\ \text { * Craigdarroch Castle } & \text { Swiftsure Lightship Classic } \\ \text { * Pacific Rim National Park } & \text { Museums }\end{array}$

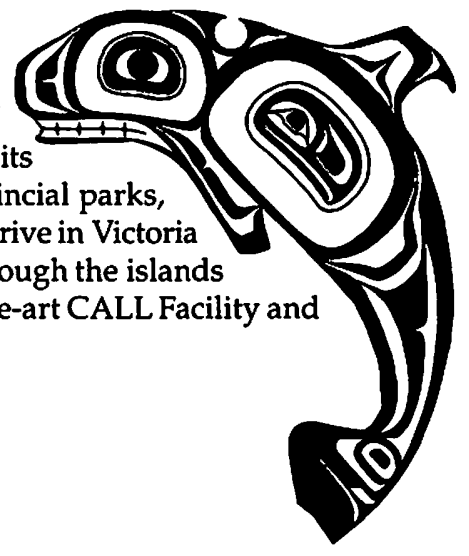

"To realize Victoria you must take all that the eye admires in Bournemouth, Torquay, the Isle of Wight, the Happy Valley at Hong Kong, the Doon, Sorrento and Camp's Bay - add reminiscences of the Thousand Islands and arrange the whole around the Bay of Naples with some Himalayas for background."

- Rudyard Kipling

\section{For more FLEAT III at UVIC information:}

\author{
E-mail: FLEATIII@CALL.UVIC.CA \\ Phone: (604) 721-8294 \\ FAX: (604) 721-8778 \\ WWW: http://ikra.call.uvic.ca/LangCen/ \\ FLEAT/fleat1.html
}

Foreign Language Education And Technology 